\title{
Bone marrow CFU-GM and human tumor xenograft efficacy of three antitumor nucleoside analogs
}

\author{
REBECCA G. BAGLEY ${ }^{1}$, STEPHANIE ROTH ${ }^{2}$, LESLIE S. KURTZBERG ${ }^{1}$, CECILE ROULEAU ${ }^{1}$, \\ MIN YAO ${ }^{1}$, JENNIFER CRAWFORD ${ }^{2}$, ROY KRUMBHOLZ ${ }^{2}$, DENNIS LOVETT ${ }^{2}$, \\ STEVEN SCHMID ${ }^{2}$ and BEVERLY A. TEICHER ${ }^{1}$
}

${ }^{1}$ Genzyme Corporation, Framingham, MA 01701; ${ }^{2}$ Genzyme Corporation, San Antonio, TX, USA

Received December 23, 2008; Accepted February 11, 2009

DOI: 10.3892/ijo_00000260

\begin{abstract}
Nucleoside analogs are rationally designed anticancer agents that disrupt DNA and RNA synthesis. Fludarabine and cladribine have important roles in the treatment of hematologic malignancies. Clofarabine is a next generation nucleoside analog which is under clinical investigation. The bone marrow toxicity, tumor cell cytotoxicity and human tumor xenograft activity of fludarabine, cladribine and clofarabine were compared. Mouse and human bone marrow were subjected to colony forming (CFU-GM) assays over a 5-log concentration range in culture. NCI-60 cell line screening data were compared. In vivo, a range of clofarabine doses was compared with fludarabine for efficacy in several human tumor xenografts. The $\mathrm{IC}_{90}$ concentrations for fludarabine and cladribine for mouse CFU-GM were $>30$ and $0.93 \mu \mathrm{M}$, and for human CFU-GM were 8 and $0.11 \mu \mathrm{M}$, giving mouse to human differentials of $>3.8$ - and 8.5-fold. Clofarabine produced $\mathrm{IC}_{90} \mathrm{~s}$ of $1.7 \mu \mathrm{M}$ in mouse and $0.51 \mu \mathrm{M}$ in human CFU-GM, thus a 3.3 -fold differential between species. In the NCI-60 cell line screen, fludarabine and cladribine showed selective cytotoxicity toward leukemia cell lines while for clofarabine there was no apparent selectivity based upon origin of the tumor cells. In vivo, clofarabine produced a dose-dependent increase in tumor growth delay in the RL lymphoma, the RPMI-8226 multiple myeloma, and HT-29 colon carcinoma models. The PC3 prostate carcinoma was equally responsive to clofarabine and fludarabine. Bringing together bone marrow toxicity data, tumor cell line cytotoxicity data, and human tumor xenograft
\end{abstract}

Correspondence to: Rebecca G. Bagley, Genzyme Corporation, 49 New York Avenue, Framingham, MA 01701, USA

E-mail: rebecca.bagley@genzyme.com

Abbreviations: CFU-GM, granulocyte-macrophage-colony forming unit; PBS, phosphate-buffered saline; DMSO, dimethyl sulfoxide; FBS, fetal bovine serum; rm, recombinant mouse; rh, recombinant human; MTD, maximum tolerated dose

Key words: clofarabine, cladribine, fludarabine, bone marrow CFU-GM, tumor xenografts efficacy provides valuable information for the translation of preclinical findings to the clinic.

\section{Introduction}

The potential utility of false nucleotides and nucleosides as anticancer agents was recognized very early in the development of chemotherapeutic drugs. Nucleotide and nucleoside analogs are examples of rationally designed agents developed based upon known biochemistry occurring in metabolic pathways toward DNA synthesis. Both pyrimidine and purine structures have been explored. Fluoropyrimidines, exemplified by 5fluorouracil, mimic thymine and uracil. 5-Fluorouracil has been a useful therapeutic agent for the treatment of colorectal cancer for more than 50 years (1). Pyrimidine nucleoside analogs especially cytosine arabinoside (AraC) and 2'2'difluoro-deoxycytosine (gemcitabine) are important anticancer agents. Gemcitabine is outstanding in this class for solid tumor clinical activity in pancreatic cancer (2).

Thiopurines including 6-mercaptopurine and 6-thio-guanine have also been in clinical use as antineoplastic agents for more than 50 years. These drugs have found application in the treatment of acute lymphoblastic leukemia (ALL) in children and in acute myelogenous leukemia in adults (3). The adenosine analogs, 2-chlorodeoxyadenosine (cladribine) and 9-ß-arabinofuranosyl-2-fluoroadenosine monophosphate (fludarabine), and 2-deoxycoformycin (pentostatin) have important clinical activity in chronic leukemias and lymphomas (3). The adenosine derivative, clofarabine (2-chloro-9-(2deoxy-2-fluoro-ß-D-arabinofuranosyl)-9H-purin-6-amine), was prepared as a second generation nucleoside based upon clinical experience compared to cladribine and fludarabine (4). Clofarabine was granted accelerated approval by the FDA for the treatment of pediatric patients with relapsed or refractory acute lymphoblastic leukemia in 2004 (5).

Fludarabine was the first adenosine analog to move forward in the clinic. The 2-fluoro substitution makes the compound resistant to deamination by adenosine deaminase and administration as the monophosphate provides water solubility (3). Fludarabine is rapidly dephosphorylated in circulation to form the nucleoside 2-fluoro-9- $\beta$-arabinofuranosyladenosine (F-araA). F-araA enters cells by a carrier-mediated active transporter and is phosphorylated by deoxycytidine kinase to F-araATP. F-araATP inhibits DNA polymerase $\alpha$ by acting 
as an alternative substrate, inhibits ribonucleotide reductase, DNA primase and DNA ligase resulting in DNA deletions and mutations. F-araAMP is a DNA chain terminator when incorporated in DNA. F-araA can also be incorporated in RNA thereby terminating transcription.

Cladribine, 2-chlorodeoxyadenosine (2CdA), is about 100-times more potent as a cytotoxin against human T-lymphoblasts in culture than is fludarabine (3). Like F-araA, cladribine is actively transported via nucleoside transporters and accumulates in cells. Cladribine is also relatively resistant to deamination by adenosine deaminase. Cladribine is phosphorylated by deoxycytidine kinase and has an affinity for deoxycytidine kinase that is about 120 -fold greater than that of F-araA. 2-Chlorodeoxy-ATP accumulates in cells that have high levels of nucleoside transporters and deoxycytidine kinase, primarily lymphoid cells. 2-Chlorodeoxyadenosine is incorporated into DNA resulting in DNA strand breaks and termination of DNA synthesis. At high intracellular concentrations 2-chloro-ATP inhibits ribonucleotide reductase and causes an imbalance in deoxyribonucleotide triphosphate pools. 2-Chloro-deoxyadenosine is also toxic to quiescent cells by interfering with DNA repair and triggering apoptosis (3).

Clofarabine, like the other nucleoside analogs, enters cells primarily by the nucleoside transporters and, at high concentrations, by passive diffusion through the cell membrane. Inside of the cell, clofarabine is phosphorylated in what is now known to be a stepwise process (6). Deoxycytidine kinase is responsible for the formation of the monophosphate form of clofarabine. Deoxycytidine kinase is not cell cycle-regulated, thus the monophosphorylated forms of the nucleoside analogs are formed in cycling and quiescent cells (4). The efficiency of clofarbine phosphorylation by deoxycytidine kinase is greater than that of cladribine or fludarabine. The phosphorylated forms of nucleoside analogs are generally retained in cells, although increased cellular retention of phosphorylated clofarabine metabolites compared with other nucleoside analogs may be one reason for the increased potency of clofarabine. While formation of the monophosphorylated species of fludarabine by deoxycytidine kinase appears to be the critical rate-limiting step in the activation, the rate-limiting step in the synthesis of clofarabine tri-phosphate appears to be the conversion of clofarabine monophosphate to clofarabine diphosphate by a purine nucleotide monophosphate kinase (7). Clofarabine triphosphate competes with dATP for DNA polymerases- $\alpha$ and $-\varepsilon$ leading to chain termination and strand breaks. Clofarabine triphosphate is also a potent inhibitor of ribonucleotide reductase through binding to the regulatory subunit $(8,9)$. The cellular damage produced by these events and direct effects of clofarabine on mitochondria result in the release of cytochrome $\mathrm{c}$ from the mitochondria and activation of apoptotic pathways (10). Like other nucleoside analogs, clofarabine is cytotoxic toward both cycling and quiescent cells.

Bone marrow is critically sensitive to nucleoside analogs (11). It is important to understand the toxicity of agents to bone marrow, and to determine whether bone marrow progenitor cells will have greater or less sensitivity to the agent than human malignant cells. Bone marrow granulocytemacrophage-colony forming unit (CFU-GM) assays that compare the sensitivity of bone marrow cells across species are useful in predicting the blood levels of an agent that might be achieved in patients using blood levels tested in preclinical efficacy and safety studies as a guide. Mouse bone marrow is less sensitive to many cytotoxic agents than is human bone marrow, allowing blood levels in preclinical efficacy testing that can not be achieved in patients (11-15). An efficacious level of a compound with smaller or no differential in bone marrow progenitor sensitivity among species may have a better potential for reaching similar blood levels in patients as in mice. If bone marrow toxicity is dose-limiting, these compounds may be more likely to be successful in reaching therapeutic doses. Pessina (11) suggested that through the use of the ratio of mouse/human CFU-GM IC $\mathrm{I}_{90}$ values and the mouse MTD that the human MTD of a compound could be predicted and thus the potential for achieving a therapeutic blood level in patients estimated.

The current study compares the bone marrow CFU-GM and tumor cell growth inhibitory activity from the NCI-60 panel of three nucleoside analogs: cladribine, fludarabine, and clofarabine, and examines the activity of fludarabine and clofarabine in several human tumor xenograft models.

\section{Materials and methods}

Materials. Fludarabine (2-fluoro-9- $\beta$-arabinofuranosyladenosine) and cladribine (2-chloro-2'deoxyadenosine) were purchased from Sigma-Aldrich Chemical Co. (St. Louis $\mathrm{MO})$. Because the studies conducted were in cell culture, the non-phosphorylated form of fludarabine was used. Fludarabine was formulated as a stock solution of $20 \mathrm{mg} / \mathrm{ml}$ in dimethylformamide. Cladribine was formulated as a stock solution of $10 \mathrm{mg} / \mathrm{ml}$ in 4:1 methanol:water. Clofarabine (2chloro-9-(2-deoxy-2-fluoro-ß-D-arabinofuranosyl)-9H-purin6-amine) was available in-house as a stable white solid. Clofarabine was formulated in a stock solution of $1 \mathrm{mg} / \mathrm{ml}$ in normal saline. For cell culture, aliquots $(500 \mu 1)$ were made in sterile, capped polypropylene tubes and stored frozen at $-20^{\circ} \mathrm{C}$ until use. For colony-forming assays, a single aliquot of each compound was thawed the day of the assay, and dilutions were prepared with RPMI-1640/5\% FBS (Invitrogen, Carlsbad, CA).

For xenograft studies, fludarabine $(12.5 \mathrm{mg} / \mathrm{ml})$ (fludarabine phosphate for injection; Fludara) was purchased from Teva/GensiaSicor Pharmaceuticals (Irvine, CA) and was formulated in normal saline containing $0.05 \%$ Tween- 80 . Clofarabine $(6.12$ and $1.9 \mathrm{mg} / \mathrm{ml})$ was formulated in normal saline containing $0.05 \%$ Tween-80. Compounds were prepared freshly for injection into mice. Compounds were administered in volumes of $0.1 \mathrm{ml} / 10 \mathrm{gr}$ body weight.

Mouse bone marrow. Male Balb/c mice were purchased from Charles River Laboratories (Wilmington, MA) at 6-8 weeks of age and used for studies at 7-10 weeks of age. The mice were housed four to eight per cage, had free access to tap water, were fed a normal diet and observed daily. The procedures were carried out according to a protocol approved by the Institutional Animal Care and Use Committee in accordance with the Federal Animal Welfare Act (9 CFR, 1992) and were conducted in an AAALAC accredited facility. 
For bone marrow collection, naïve mice were sacrificed by inhalation of carbon dioxide. To ensure a sterility of the bone marrow, the sacrificed donor mouse was placed in a biological laminar flow hood and the whole body was sprayed with a $70 \%$ ethanol solution. A skin incision is made throughout the whole hind limb from mid-point of inguinal ligament to the medial side of the foot. The muscle and other connective tissues were removed and both tibias and the femurs were extracted. The bone medullary cavity was accessed by removing the epiphysis of the tibia or the femur located at the end of long bones. A blunt syringe needle (27G) was inserted into the medullary cavity and the cavity was flushed with $2 \mathrm{ml}$ of sterile RPMI-1640/5\% FBS until the color of bone shaft became pale indicating removal of the bone marrow. The resulting cellular suspension was collected into a $50 \mathrm{ml}$ conical bottom tube and kept on wet ice. Approximately 25 million cells were obtained from each mouse (15).

Bone marrow CFU-GM assay. For mouse CFU-GM assays, freshly isolated mouse bone marrow cells were cultured in MethoCult (no. M3534) containing the cytokines rmSCF, rmIL-3, and rhIL-6 (StemCell Technologies, Vancouver, Canada).

For human CFU-GM assays, viable human bone marrow cells (purchased as frozen vials from All Cells, LLC via StemCell Technologies, no. ABM009) were prepared with DNase treatment (no. 07900, StemCell Technologies), washed in a protocol described by the vendor, and cultured. The culture medium used was MethoCult GF (no. H4534), containing the cytokines hSCF, hGM-CSF, hIL-3 (StemCell Technologies).

Both the human and mouse MethoCult mediums were received frozen in $100 \mathrm{ml}$ volumes. Upon receipt, bottles were thawed overnight at $4^{\circ} \mathrm{C}$, and divided into $3 \mathrm{ml}$ aliquots in sterile $15 \mathrm{ml}$ tubes The MethoCult mediums solidify at $37^{\circ} \mathrm{C}$, and were not warmed to greater than room temperature until cells and compounds were added immediately prior to transfer to $37^{\circ} \mathrm{C}$. The MethoCult medium aliquots were refrozen at $-20^{\circ} \mathrm{C}$ until thawing at $4^{\circ} \mathrm{C}$ overnight before the assay.

For experiments, $150 \mu \mathrm{l}$ of $20 \mathrm{x}$ concentration of the compounds, along with $150 \mu 1$ of a suspension of mouse or human bone marrow cells, were added to the $3 \mathrm{ml}$ tube of thawed MethoCult medium and vigorously mixed by vortex. Final cell concentrations were $4 \times 10^{4}$ cells/plate for mouse cells, $8 \times 10^{4}$ cells/plate for human cells. Tubes were then allowed to sit undisturbed for 10-15 min until the air bubbles dissipated. A blunt needle attached to a 3-ml syringe was used to collect $2.5 \mathrm{ml}$ of the cell suspension, the air was voided from the syringe, and $1 \mathrm{ml}$ was placed in the center of duplicate $100 \mathrm{~cm}^{2}$ culture dishes. Dishes were gently rotated to allow even coverage of the bottom surface of each dish and then placed in a $37^{\circ} \mathrm{C}$ incubator for colony formation for 13 days for mouse bone marrow and 15 days for human bone marrow. Colonies were defined as clusters containing 30 or more cells.

Human and mouse bone marrow progenitor cells were continuously exposed to a concentration range of fludarabine, cladribine or clofarabine in three independent CFU-GM colony formation experiments. The compound concentrations were made in half-log intervals covering $5 \operatorname{logs}$ (10 concentrations). The $\mathrm{IC}_{50}$ and $\mathrm{IC}_{90}$ values and the $95 \%$ confidence interval for each compound for human and mouse bone marrow were determined by non-linear regression analysis (15).

NCI-60 cell line panel. National Cancer Institute Developmental Therapeutics Program concentration response curves, $\mathrm{GI}_{50} \mathrm{TGI}_{50}$, and $\mathrm{LC}_{50}$ data were accessed at: http://dtp.nci. gov/compare-web-public_compare. Data were retrieved for cladribine (NSC 105014), fludarabine phosphate (NSC 312887) and clofarabine (NSC 606869). The 50\% growth inhibitory concentration $\left(\mathrm{GI}_{50}\right)$ data from the NCI-60 cell line panel screen were expressed as micromolar concentrations. For these studies human tumor cells were exposed to the compounds for $48 \mathrm{~h}$. While the cell lines examined with each compound were not identical, there was a large degree of overlap across the three compounds.

Tumor lines. The RL lymphoma is a mature, EBV-negative, $\mathrm{CD} 20^{+} \mathrm{B}$ cell line from a diffuse large-cell lymphoma and carries a chromosomal marker $\mathrm{t}(14,18)(\mathrm{q} 32 ; \mathrm{q} 21)(16)$. The RPMI-8226 line is a B lymphocyte plasmacytoma, a cell line established from a 61-year old male in the mid-1960s (17). The cell line is most often described as multiple myeloma. The human PC-3 prostate carcinoma line was developed from a bone metastasis of a grade IV prostate adenocarcinoma from a 62-year old patient (18). The PC-3 line is androgen independent, exhibits low acid phosphatase and testosterone$5-\alpha$ reductase activities. The HT-29 colorectal carcinoma cell line was established in 1964 from the primary tumor of a 44-year old female (19).

Human tumor xenografts. The efficacy of fludarabine phosphate and clofarabine was compared in human tumor xenograft studies. All procedures were carried out according to a protocol approved by the Institutional Animal Care and Use Committee in accordance with the Federal Animal Welfare Act (9 CFR, 1992) and were conducted in an AAALAC accredited facility. SCID mice from Frederick Cancer Research and Development Center (Frederick, MD) or nu/nu mice from Harlan Sprague Dawley (Indianapolis, IN) were implanted subcutaneously with a $4 \mathrm{mg}$ tumor fragment, and treatments were initiated when tumors reached $100-200 \mathrm{~mm}^{3}$. At the time the tumor volumes reached $100-200 \mathrm{~mm}^{3}$, the animals were pair-matched into treatment $(n=8-10)$ or control groups $(\mathrm{n}=8-10)$.

For experiments with the human RL lymphoma, RPMI8226 multiple myeloma, PC-3 prostate carcinoma or HT-29 colon carcinoma xenografts, fludarabine $(125 \mathrm{mg} / \mathrm{kg}$ once daily for 5 days or 60 or $90 \mathrm{mg} / \mathrm{kg}$ 3-times per day daily for 9 days) was administered by intraperitoneal injection. Clofarabine $(60 \mathrm{mg} / \mathrm{kg}$ once per day for 5 days or $8,12,13.3,18$ or $20 \mathrm{mg} /$ $\mathrm{kg} 3$-times per day for 9 days) was administered by intraperitoneal injection or (12 or $20 \mathrm{mg} / \mathrm{kg}$ daily for 30 days) was administered orally by gavage.

Statistical analysis. Concentration-response data for bone marrow CFU-GM were analyzed using a nonlinear curve fit for a one phase exponential decay $(\mathrm{y}=a \mathrm{x} \exp (b \times x)+c)$. 
<smiles>Nc1nc(Cl)nc2c1ncn2[C@@H]1C[C@H](O)[C@@H](CO)O[C@@H]1O</smiles>

Cladribine<smiles>Nc1nc(F)nc2c1ncn2[C@@H]1O[C@H]2O[C@H](CO)[C@H](O)[C@H]1O2</smiles>

Fludarabine<smiles>Nc1nc(Cl)nc2c1ncn2[C@H]1O[C@H](CO)[C@@H](O)[C@H]1F</smiles>

Clofarabine

Figure 1. Chemical structures of cladribine, fludarabine and clofarabine are shown. Fludarabine is shown in the non-phosphate form that was used in the bone marrow CFU-GM experiments. Fludarabine monophosphate was used in the NCI-60 cell line panel screen and in the human tumor xenograft studies.

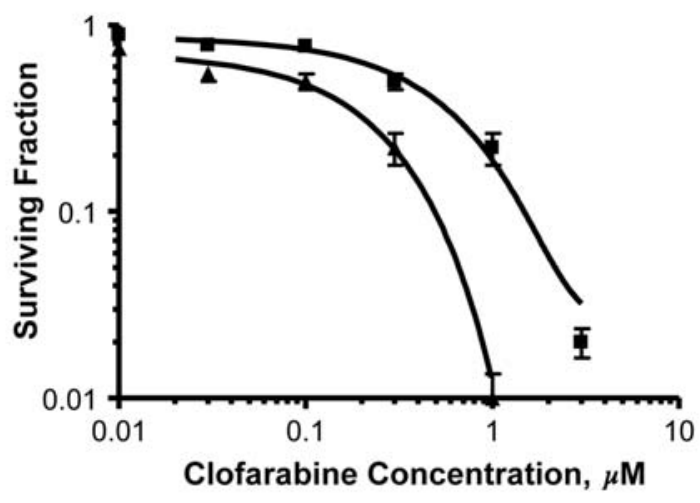

Mouse bone marrow CFU-GM

$\Delta$ Human bone marrow CFU-GM
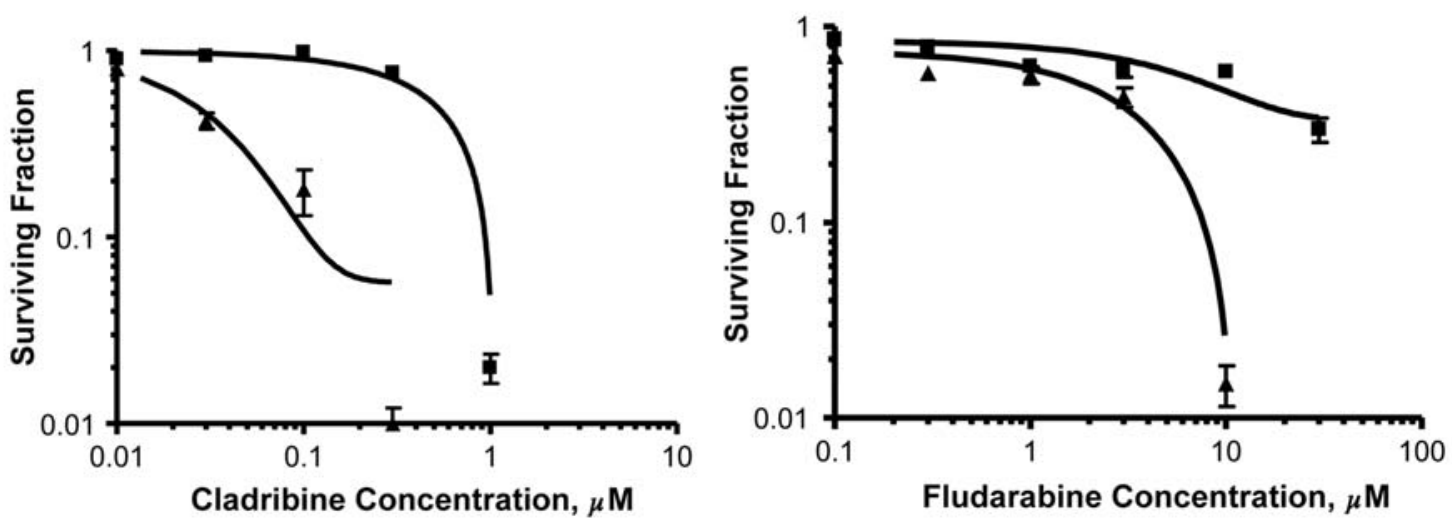

Figure 2. Concentration response curves for each of three nucleoside analogs in mouse ( $\mathbf{})$ and human ( $\mathbf{\Delta})$ bone marrow CFU-GM. The data are the means of two independent experiments; bars are SD.

The $\mathrm{IC}_{50}$ and $\mathrm{IC}_{90}$ values for each compound for human and mouse bone marrow were determined from the curves in Fig. 2 using GraphPad Prism software.

Tumor volumes were calculated using the formula $\left(w^{2} \times 1\right) / 2$ where ' $w$ ' is the width of the tumor and ' 1 ' is the length of the tumor. Individual mice were weighed and tumor measurements taken by calipers twice weekly. Body weights for individual mice were measured at the time of each tumor measurement. The data are presented in Figs. 4-6 as mean tumor volume \pm SEM. The maximal percent body weight and day of occurrence are shown in Table II. Mice were euthanized when the tumors reached a predetermined volume. Tumor growth delay was obtained by determining the difference between treatment and control group mean tumor growth in days at a predetermined tumor volume.

\section{Results}

The compounds cladribine, fludarabine and clofarabine are potent cytotoxic agents for both mouse and human bone marrow CFU-GM (Fig. 1). Exposure to the compounds produced killing of cells in an exponential manner. The concentration response curves are shown in Fig. 2. For cladribine and clofarabine, concentrations killing 50 and $90 \%$ 
Table I. Mouse and human bone marrow CFU-GM IC ${ }_{50}$ and $\mathrm{IC}_{90}$ values for three nucleoside analogs in micromolar concentrations are listed. ${ }^{\mathrm{a}}$

Clofarabine Cladribine Fludarabine

$\begin{array}{llll}\begin{array}{l}\text { Mouse CFU-GM } \\ \mathrm{IC}_{50}(\mu \mathrm{M})\end{array} & 0.37 & 0.52 & 9.5 \\ \mathrm{IC}_{90}(\mu \mathrm{M}) & 1.7 & 0.93 & >30 \\ \text { Human CFU-GM } & & & \\ \mathrm{IC}_{50}(\mu \mathrm{M}) & 0.10 & 0.028 & 2.2 \\ \mathrm{IC}_{90}(\mu \mathrm{M}) & 0.51 & 0.11 & 8.0 \\ \text { Ratio mouse:human } & 3.7 \text {-fold, } & 18.6 \text {-fold, } & 4.3 \text {-fold, } \\ \left(\mathrm{IC}_{50}, \mathrm{IC}_{90}\right) & 3.3 \text {-fold } & 8.5 \text {-fold } & >3.8 \text {-fold }\end{array}$

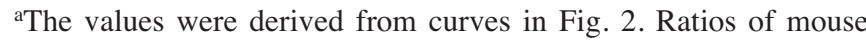
bone marrow $\mathrm{CFU}-\mathrm{GM}$ to human bone marrow $\mathrm{IC}_{50}$ and $\mathrm{IC}_{90}$ are given.

of the cells were achieved or nearly achieved. Fludarabine cytotoxicity reached $\mathrm{IC}_{50}$ and $\mathrm{IC}_{90}$ values in human bone marrow CFU-GM but did not reach an $\mathrm{IC}_{90}$ concentration in mouse bone marrow CFU-GM. Human and mouse bone marrow CFU-GM IC ${ }_{50}$ concentrations were 2- to 5-fold lower than the corresponding $\mathrm{IC}_{90}$ concentrations (Table I). Human bone marrow CFU-GM was more sensitive to the cytotoxicity of the compounds than was mouse bone marrow CFU-GM.

Cladribine and clofarbine were more potent cytotoxic agents than fludarabine toward human bone marrow CFU-GM. Cladribine had the largest differential between cytotoxicity toward mouse bone marrow CFU-GM and human bone marrow CFU-GM. The ratios of the mouse and human bone marrow $\mathrm{CFU}-\mathrm{GM}$ at the $\mathrm{IC}_{50}$ and $\mathrm{IC}_{90}$ concentrations were calculated (Table I). For cladribine, the ratios were greater than or near to 10 -fold, for clofarabine the ratios were about 4-fold and for fludarabine the ratios were greater than or equal to 4-fold.

While in the bone marrow CFU-GM assay, cells were continuously exposed to the compounds for 12-14 days, in the NCI-60 human tumor cells line panel screen the compound exposure time was only $48 \mathrm{~h}$. The NCI-60 human tumor cells line panel screen data indicate very different patterns and potencies of cytotoxicity for the three nucleosides studied (Fig. 3). Even with a short exposure time ( $48 \mathrm{~h}$ ) to clofarabine, cell lines of multiple origins including renal cell carcinoma, non-small cell lung cancer, melanoma, leukemia, colon cancer and breast cancer have $\mathrm{IC}_{50}$ concentrations lower than the $\mathrm{IC}_{50}$ concentration of $0.1 \mu \mathrm{M}$ for clofarabine in human bone marrow CFU-GM (Fig. 3). Cladribine is very toxic to human bone marrow CFU-GM and only the human leukemia cell line $\mathrm{K}-562$ is more sensitive to cladribine than is human bone marrow CFU-GM. The monophosphate form of fludarabine was tested in the NCI-60 human tumor cells line panel screen which lowers the potency of the compound; however, like cladribine, the cell lines most sensitive to fludarabine are mainly leukemia-derived lines. Clofarabine is a more potent cytotoxic agent toward human tumor cells than are cladribine and fludarabine. While cladribine and fludarabine show selectivity for killing leukemia cells, cytotoxicity pattern of clofarabine does not indicate selectivity based upon tissue of origin but rather provide a broader tumor spectrum of cytotoxicity (Fig. 3).

In vivo, a range of clofarabine doses and schedules $(60 \mathrm{mg} /$ $\mathrm{kg}$ once per day for 5 days or 8 or $12 \mathrm{mg} / \mathrm{kg}$ 3-times per day for 9 days) were tested for efficacy in comparison with fludarabine (125 mg/kg once daily for 5 days) in subcutaneously implanted human RL lymphoma (Fig. 4). Tumor growth delays produced by these dose regimens of clofarabine showed strong schedule dependency. The $60 \mathrm{mg} / \mathrm{kg}$ daily for 5 days regimen resulted in 24 days of tumor growth delay from a total clofarabine

Table II. Tumor growth delay (TGD) and percent maximal body weight loss for human tumor xenograft studies with clofarabine and fludarabine administered at the maximally efficacious dose regimens. ${ }^{\mathrm{a}}$

\begin{tabular}{llcc}
\hline Human tumor & \multicolumn{1}{c}{ Treatment } & TGD \pm SEM, days & \% Maximum body weight loss \\
\hline RL lymphoma & Clofarabine $(12 \mathrm{mg} / \mathrm{kg})$ & $51 \pm 4$ & 13 (day 27) \\
& Fludarabine $(125 \mathrm{mg} / \mathrm{kg})$ & $6 \pm 3$ & 0 \\
RPMI-8226 multiple nyeloma & Clofarabine $(12 \mathrm{mg} / \mathrm{kg})$ & $18 \pm 3$ & $13($ day 22$)$ \\
& Fludarabine $(60 \mathrm{mg} / \mathrm{kg})$ & None & 0 \\
PC-3 prostate carcinoma & Clofarabine $(13.3 \mathrm{mg} / \mathrm{kg})$ & $29 \pm 4$ & 20 (day 20) \\
& Fludarabine $(90 \mathrm{mg} / \mathrm{kg})$ & $30 \pm 3$ & 18 (day 20) \\
& Clofarabine $(12 \mathrm{mg} / \mathrm{kg})$ & $48 \pm 5$ & 14.8 (day 31)
\end{tabular}

a Data were derived from the tumor growth curves shown in Figs. 4-6. 


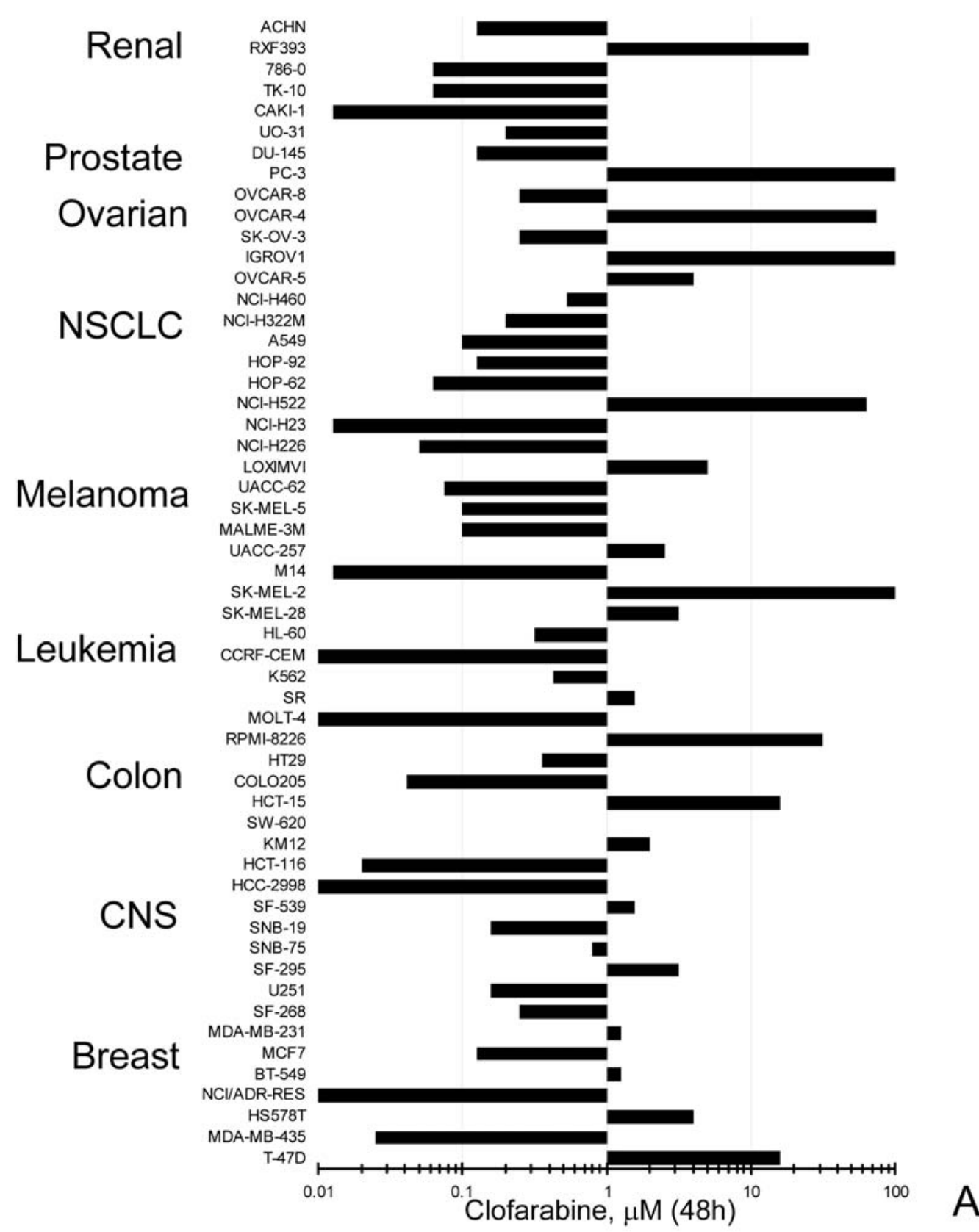

Figure 3. NCI-60 cell line panel screening $\mathrm{GI}_{50}$ data for clofarabine (A), cladribine (B), and fludarabine monophosphate (C) are shown in micromolar. Each chart is centered at $1 \mu \mathrm{M}$ concentration. The cells lines tested for each compound was not identical. The sequence of cell types is the same in each chart.

dose of $300 \mathrm{mg} / \mathrm{kg}$. The $12 \mathrm{mg} / \mathrm{kg}$ 3-times per day for 9 days regimen resulted in 51 days of tumor growth delay from a total clofarabine dose of 324 and $8 \mathrm{mg} / \mathrm{kg} 3$-times per day for 9 days regimen produced 41 days of tumor growth delay from a total clofarabine dose of $216 \mathrm{mg} / \mathrm{kg}$. By contrast, fludarabine monophosphate $(125 \mathrm{mg} / \mathrm{kg})$ administered once daily for 5 days or a total fludarabine dose of $625 \mathrm{mg} / \mathrm{kg}$, produced a tumor growth delay of 6 days in the RL lymphoma. The most efficacious clofarabine regimen $(12 \mathrm{mg} / \mathrm{kg})$ produced $13 \%$ body weight loss in the mice; while fludarabine (125 $\mathrm{mg} / \mathrm{kg}$ ) administration did not cause weight loss (Table II). A similar study was performed with the RPMI-8226 multiple myeloma (Fig. 4). Clofarabine, administered by intraperitoneal injection 3-times per day for 9 days, was efficacious at each of the three doses tested in the RPMI-8226 multiple myeloma with tumor growth delays of 16-18 days for doses of 8,12 , and $18 \mathrm{mg} / \mathrm{kg}$ without a dose response effect. Fludarabine monophosphate $(60 \mathrm{mg} / \mathrm{kg})$ administered by intraperitoneal injection 3-times per day for 9 days had no antitumor activity in the RPMI-8226 multiple myeloma xenograft due to toxicities. As with the RL lymphoma, the most efficacious clofarabine regimen $(12 \mathrm{mg} / \mathrm{kg})$ in the RPMI-8226 multiple myeloma produced $13 \%$ body weight loss in the mice; while fludarabine $(60 \mathrm{mg} / \mathrm{kg})$ administration did not cause weight loss (Table II).

The human PC-3 prostate carcinoma xenograft was equally responsive to clofarabine and fludarabine monophosphate (Fig. 5). In this model, clofarabine $(20 \mathrm{mg} / \mathrm{kg}) 3$-times per day for 9 days produced a tumor growth delay 21 days while a dose of $13.3 \mathrm{mg} / \mathrm{kg}$ of clofarabine produced 29 days of 


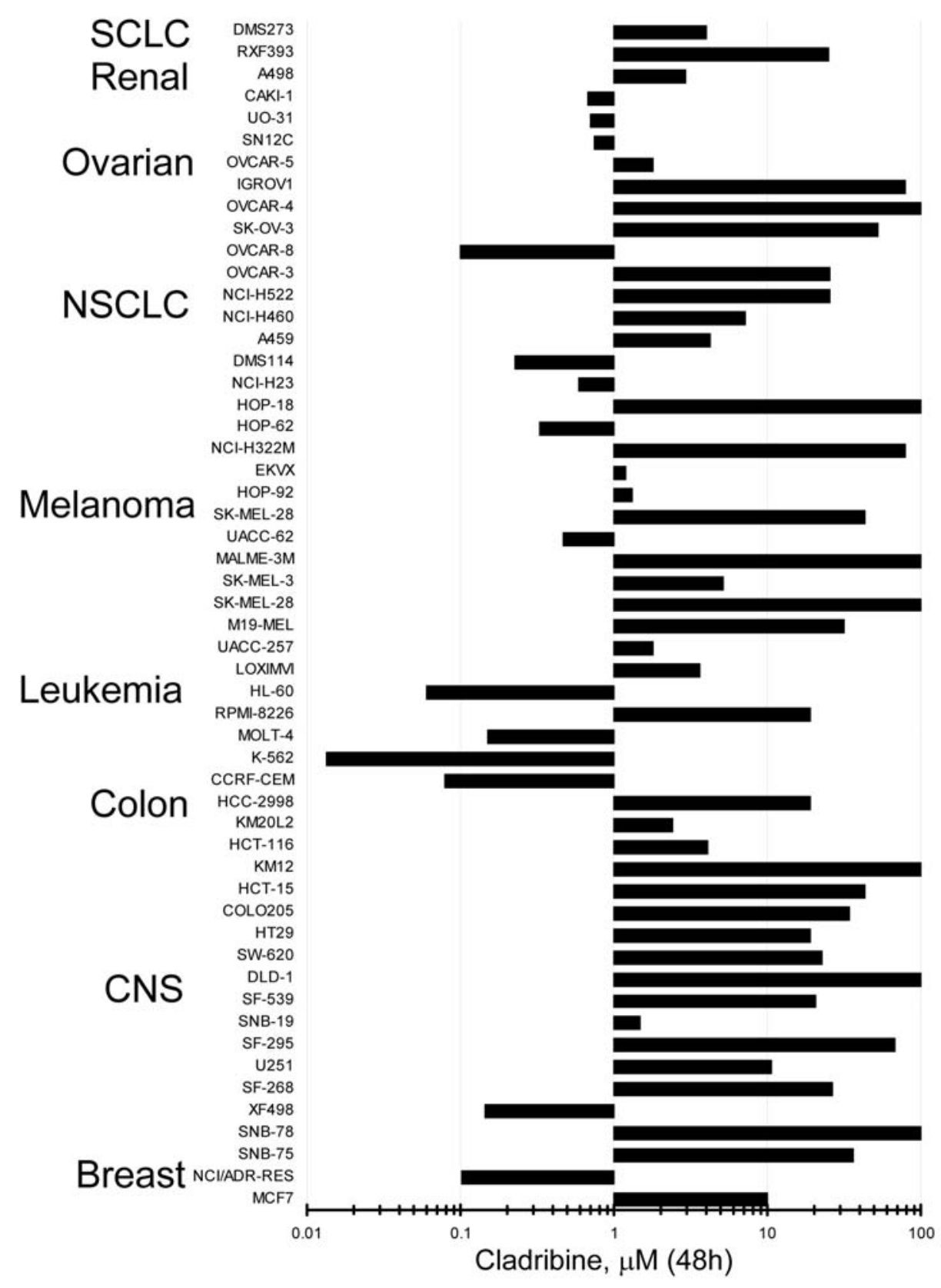

Figure 3 (continued).

tumor growth delay. The lack of correlation of response with dose may have resulted from increased toxicity of the higher clofarabine dose. Fludarabine monophosphate administration produced a dose-dependent tumor growth delay resulting in 20 and 30 days of tumor growth delay with doses of 60 and $90 \mathrm{mg} / \mathrm{kg}$ of fludarabine 3 -times per day for 9 days, respectively. The most efficacious clofarabine regimen $(13.3 \mathrm{mg} / \mathrm{kg}$ ) produced $20 \%$ body weight loss in the mice; while fludarabine $(90 \mathrm{mg} / \mathrm{kg}$ ) administration resulted in $18 \%$ body weight loss (Table II).

Clofarabine was administered orally to mice bearing human HT-29 colon carcinoma. Two dose regimens of clofarabine were tested and compared with fludarabine monphosphate administered by intraperitoneal injection. Clofarabine (12 mg/ $\mathrm{kg}$ ) administered orally once daily for 30 days for a total clofarabine dose of $360 \mathrm{mg} / \mathrm{kg}$, resulted in a tumor growth delay of 48 days in the HT-29 colon carcinoma (Fig. 6). In contrast, clofarabine $(20 \mathrm{mg} / \mathrm{kg})$ administered orally 3-times per day for 9 days for a total dose of $540 \mathrm{mg} / \mathrm{kg}$ produced 31.5 days of tumor growth delay in the HT-29 colon carcinoma. The HT-29 colon carcinoma was less responsive to fludarabine administered by intraperitoneal injection at a dose of $90 \mathrm{mg} / \mathrm{kg}$ 3-time per day daily for 9 days which produced 16 days of tumor growth delay from a total fludarabine dose of $1.24 \mathrm{~g} / \mathrm{kg}$. The most efficacious clofarabine regimen $(12 \mathrm{mg} / \mathrm{kg})$ produced $14.8 \%$ body weight loss in the mice; while fludarabine $(90 \mathrm{mg} /$ $\mathrm{kg}$ ) administration resulted in $13.5 \%$ body weight loss (Table II).

\section{Discussion}

The three analogs of adenosine examined are approved anticancer agents in clinical use. These compounds are rationally 


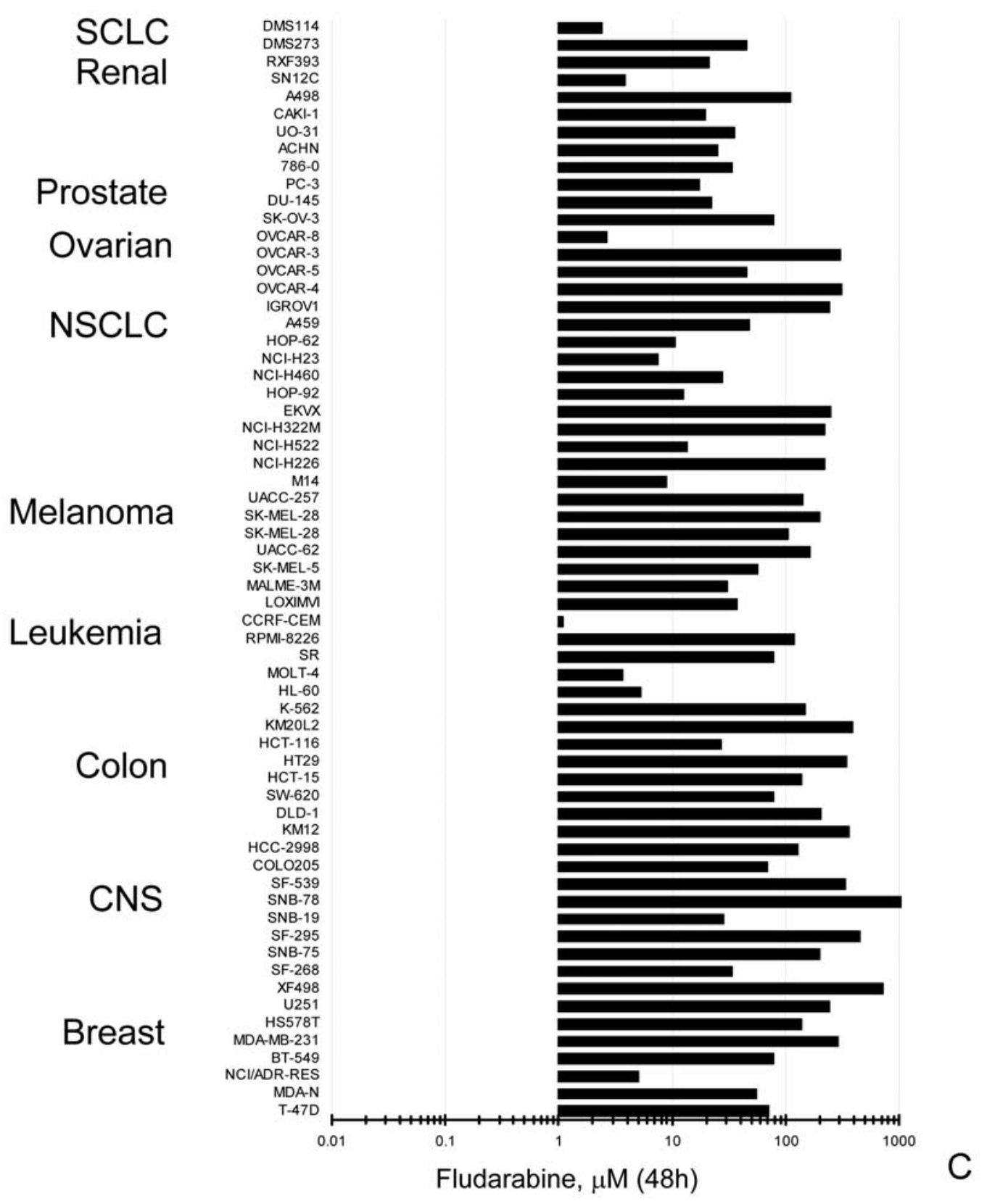

Figure 3 (continued).

designed prodrugs that avoid metabolic inactivation by adenosine deaminase and retain substrate specificity for deoxycytidine kinase. Intracellular levels of deoxycytidine kinase are one major determinant of the selectivity of these compounds for indolent lymphoid malignancies such as hairy cell leukemia and B-cell chronic lymphocytic leukemia (B-CLL) (20-23). Deoxycytidine kinase is expressed at very high levels by bone marrow $\mathrm{CD} 71^{+}$and $\mathrm{CD} 34^{+}$progenitor cells, bone marrow $\mathrm{CD}_{105^{+}}$endothelial cells, peripheral blood $\mathrm{BDCA}^{+}$dendritic cells and peripheral blood CD19+ $\mathrm{B}$-cells as well as peripheral blood $\mathrm{CD}^{+} 6^{+} \mathrm{NK}$ cells and $\mathrm{CD}^{+}$and $\mathrm{CD}^{+} \mathrm{T}$-cells. The expression of deoxycytidine kinase in these normal cells is as high as or higher than the expression in some leukemias and lymphomas. The clinical 7-day continuous infusion reigmen of $0.1 \mathrm{mg} / \mathrm{kg} /$ day of cladribine for hairy leukemia achieves a steady state concentration of 20-30 nM of the cladribine in circulation. The $\mathrm{IC}_{50}$ for cladribine in human bone marrow CFU-GM was $28 \mathrm{nM}$ and the $\mathrm{IC}_{90}$ was $110 \mathrm{nM}$ with 14 days continuous exposure illustrating the narrow therapeutic index of this drug (Table I). The primary toxicity of cladribine is bone marrow suppression with prolonged lymphocytopenia especially of CD4+ T-cells $(20,21)$. In the NCI-60 cell line panel the cell lines most sensitive to cladribine were the K562, CCRF-CEM, HL-60 and MOLT-4 leukemias; of these only MOLT-4 cells are outstandingly high expressers of deoxycytidine kinase. Interestingly, MOLT-4 cells are also very high expressers of adenosine deaminase. The classic work of Carson et al utilized CCRFCEM T-cell leukemia and WI-12 B-cell leukemia to identify cladribine as the most potent cytotoxic agent amongst a series of adenosine analogs and used mouse L1210 leukemia as the in vivo efficacy model $(24,25)$. These studies also established 


\section{Human RL Lymphoma}

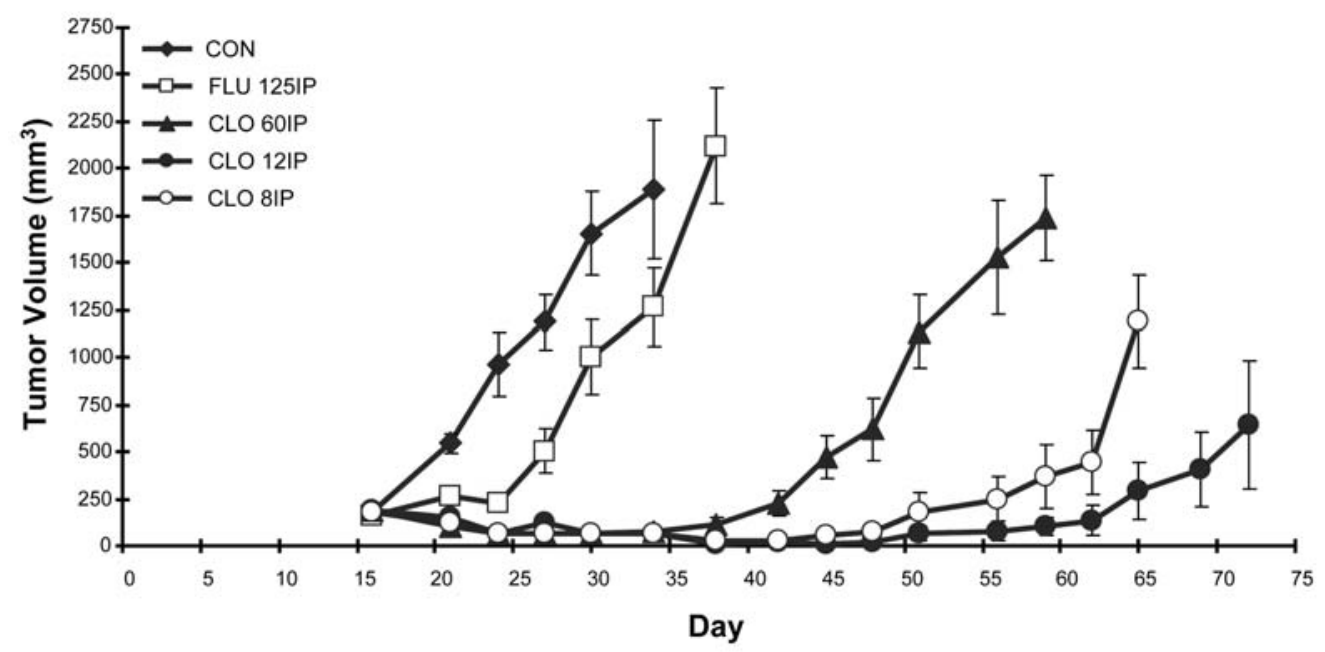

Human RPMI-8226 Multiple Myeloma

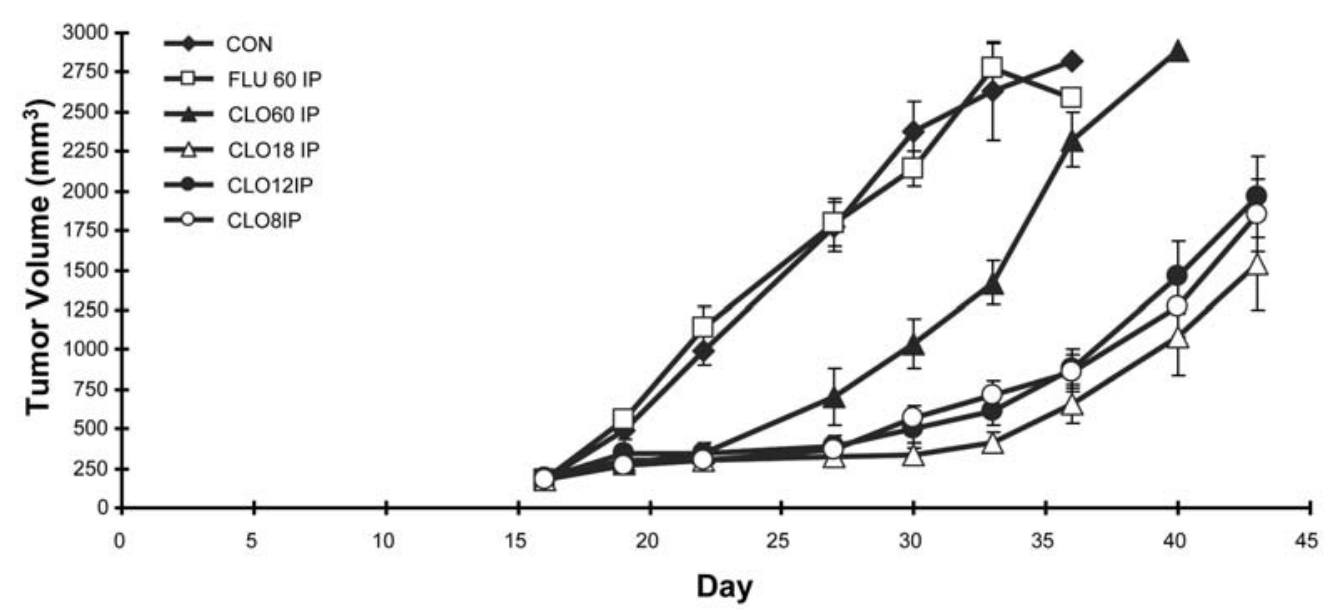

Figure 4. Growth delay of subcutaneously implanted human RL lymphoma (A) and RPMI-8226 multiple myeloma (B) tumors after treatment with clofarabine $(60 \mathrm{mg} / \mathrm{kg}$ ) daily for 5 days or $(8,12$ or $18 \mathrm{mg} / \mathrm{kg}$ ) 3 -times per day for 9 days by intraperitoneal injection or fludarabine monophosphate ( $125 \mathrm{mg} / \mathrm{kg})$ daily for 5 days or $(60 \mathrm{mg} / \mathrm{kg}) 3$-times per day for 9 days by intraperitoneal injection. The points are means for 8-10 mice; bars are SEM.

\section{Human PC-3 Prostate Carcinoma}

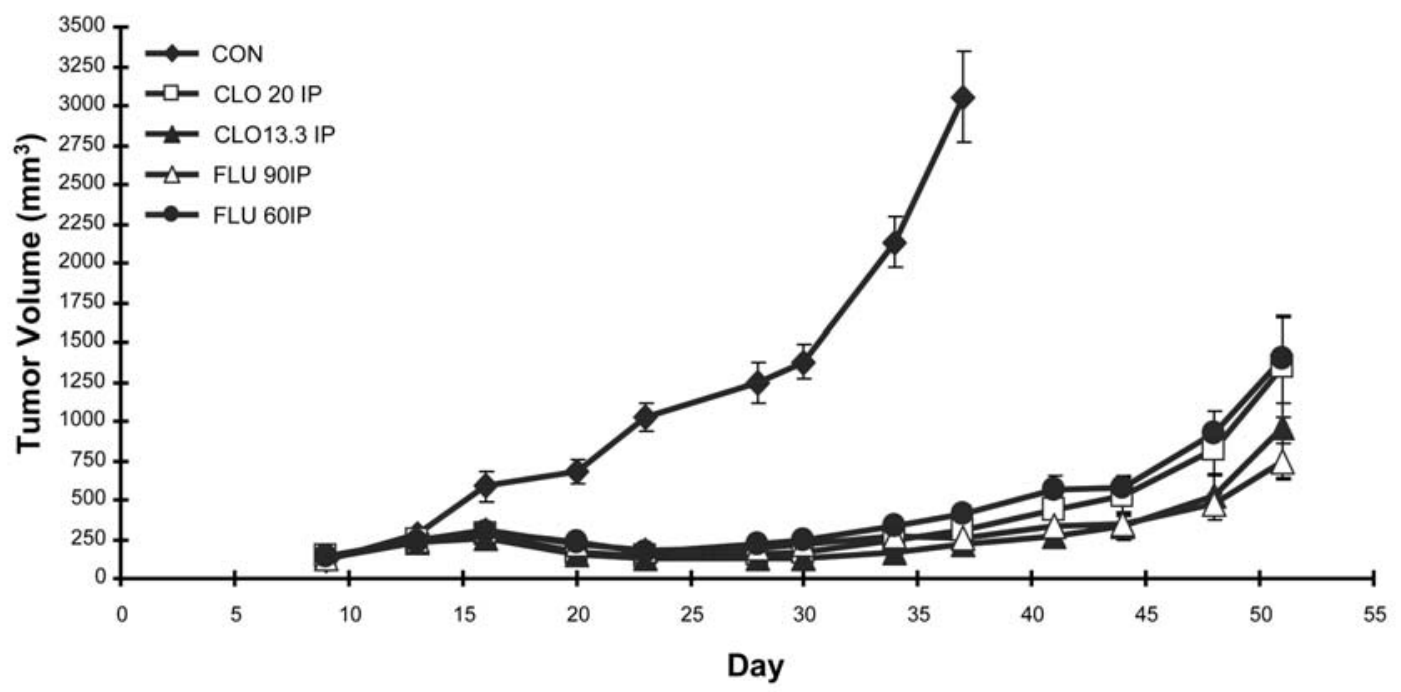

Figure 5. Growth delay of subcutaneously implanted human PC-3 prostate carcinoma tumors after treatment with clofarabine (13.3 or 20 mg/kg) 3-times per day for 9 days by intraperitoneal injection or fludarabine monophosphate $(60 \mathrm{or} 90 \mathrm{mg} / \mathrm{kg}) 3$-times per day for 9 days by intraperitoneal injection. The points are means for 8-10 mice; bars are SEM. 


\section{Human HT-29 Colon Carcinoma}

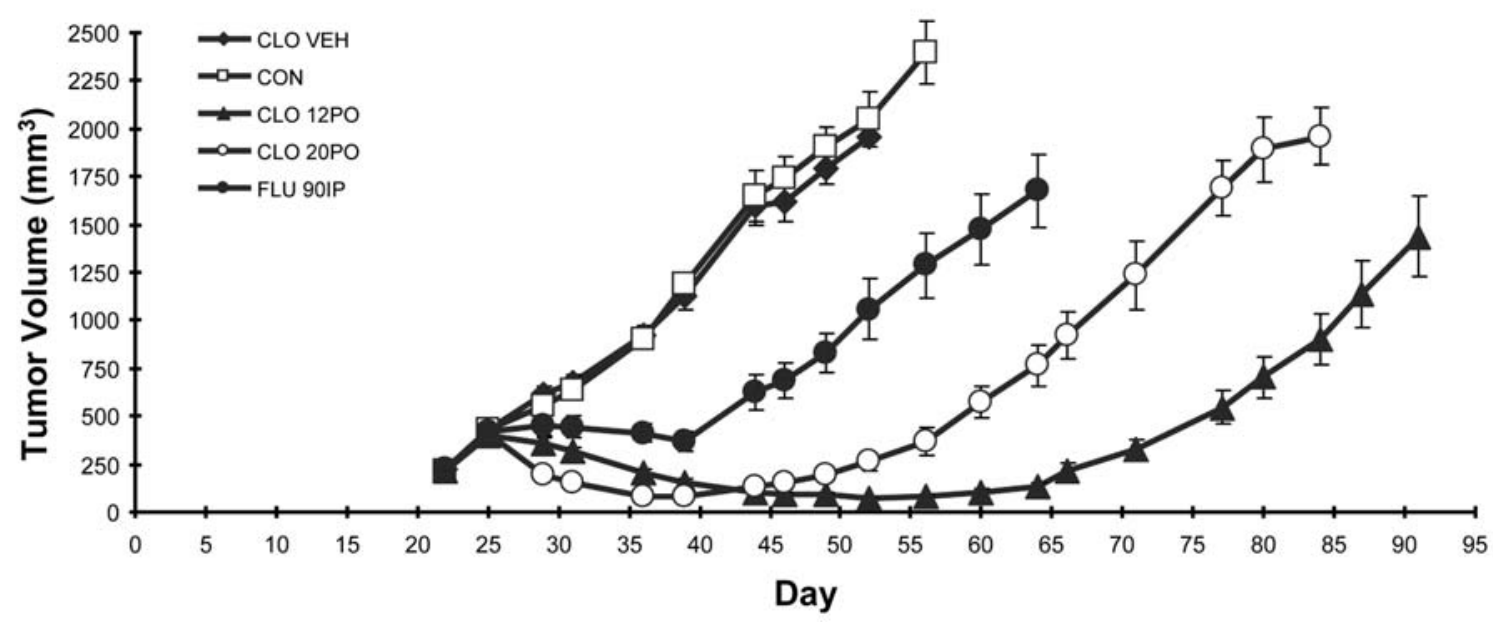

Figure 6. Growth of subcutaneously implanted human HT-29 colon carcinoma tumors after treatment with clofarabine (12 mg/kg) administered orally daily for 30 days or $(20 \mathrm{mg} / \mathrm{kg}$ ) administered orally 3-times per day for 9 days, or after treatment with fludarabine monophosphate (90 mg/kg) administered 3times per day for 9 days by intraperitoneal injection. The points are means for 8-10 mice; bars are SEM.

that cladribine was cytotoxic to both stationary phase and exponentially growing malignant B-cells and T-cells and that longer exposure times resulted in greater cell death in a concentration $\mathrm{x}$ time relationship. Clinically, cladribine produces prolonged complete remissions in most patients with hairy cell leukemia resulting in normal life-spans for many patients although minimal residual disease is common $(20,21)$.

Fludarabine is indicated for the treatment of adult B-cell chronic lymphocytic leukemia (CLL) patients who have not responded to or have progressed during treatment with at least one alkylating agent-based regimen $(26,27)$. There has been an effort to identify patients most likely to benefit from treatment with fludarabine. Three nucleoside transporters mediate fludarabine entry into cells, hENT1, hENT2 which are equilibrative nucleoside transporters, and hCNT2 and hCNT3 which are concentrative nucleoside transporters $(28,29)$. There is a correlation between hENT2 levels, fludarabine uptake and the sensitivity of CLL cells in culture to fludarabine. Tsang et al (30) found that CLL patients whose tumors express high levels of the mRNA for the human concentrative nucleoside transporter 3 (hCNT3) are likely to be resistant to fludarabine (30). An immunohistochemical study was conducted with clinical specimens and it was found that patients whose tumors had high scores for hCNT3 content had significantly shorter time to progression (TTP) after treatment with fludarabine compared with patients whose tumors had a low score for hCNT3. The median time to progression was 4.7 months compared with 11.2 months, respectively.

Clofarabine was designed to incorporate characteristics of fludarabine and cladribine. Clofarabine has several significant differences compared with fludarabine and cladribine including: i) increased resistance to deamination and phosphorolysis and hence better stability of the active cytotoxic species; ii) higher affinity to deoxycytidine kinase; iii) prolonged retention of the triphosphate compound in malignant cells (shown in leukemic blasts); and iv) potent inhibition of DNA synthesis and of ribonucleotide reductase (RNR) $(8-10,31,32)$. Clofarabine has a very different pattern of cytotoxicity than fludarabine and cladribine. As demonstrated by the NCI-60 cell line screening data, clofarabine is not selectively cytotoxic toward cell lines of hematopoietic lineage but has broad spectrum cytotoxicity (Fig. 3). Recombinant nucleoside transporters, hCNT3, hENT1 and hENT2 produced in yeast had higher affinities for clofarabine than for either fludarabine or cladribine $(29,33)$. Using nucleoside transporter deficient cells transfected to express single transporters demonstrated that cells producing hENT1 or hCNT3 had high uptakes rates for clofarabine. Gene expression data from the NCI 60-cell line panel indicate that higher expression of deoxycytidine kinase, hENT2 and, unexpectedly, ABCC5 correlates with increased sensitivity to clofarabine in the screen (34-37).

Intracellularly, clofarabine is very efficiently monophosphorylated by deoxycytidine kinase $(31,38)$. Clofarabine is also phosphorylated by deoxyguanosine kinase in the mitochondria. Furthermore, clofarabine triphosphate accumulates in cells more rapidly than do the triphosphates of cladribine and fludarabine $(39,40)$. Clofarabine triphosphate can interact efficiently with mitochondrial enzymes in ATP binding pockets and was as active as dATP in apoptosome complex stimulation of caspase activation (10). Clofarabine is more stable at acidic $\mathrm{pH}$ and has markedly better oral bioavailability than cladribine (32). In mice given oral doses of either clofarabine or cladribine, plasma levels of clofarabine were 10-times greater than plasma levels of cladribine. The increased oral bioavailability of clofarabine is an indication that clofarabine is transported differently from the other nucleosides. Clofarabine $(100 \mathrm{mg} / \mathrm{kg}$, x 5 daily) was a very effective anticancer agent against human colon carcinoma xenografts when administered orally. In fact oral administration of clofarabine was more efficacious than intravenous delivery of the same dose and schedule (41). In phase I clinical trials in patients with 
solid and hematologic cancers, the dose limiting toxicities of clofarabine were myelosupression and thrombocytopenia (42). However, in patients with myelodysplasias and acute leukemias the dose limiting toxicity was hepatotoxcity, which is different from other clinically applied nucleoside analogs (43).

Submicromolar concentrations of clofarabine inhibit proliferation, migration and tube formation of human endothelial cells in culture suggesting that clofarabine may be effective against the malignant cells and have antiangiogenic activity directed toward the vascular compartment as a component of a regimen for the treatment of solid tumors (Roy et al, Proc Am Assoc Cancer Res, abs. 235, 2006). At relatively low concentrations, clofarabine was an effective radiation sensitizer of human DLD-1 colon carcinoma cells in culture (Cariveau et al, Proc Am Assoc Cancer Res, abs. 5055, 2007). While clofarabine had modest effects as a single agent therapy for DLD-1 subcutaneous xenografts, there was marked tumor growth delay in combination with radiation therapy suggesting potential benefits of combination clofarabine with DNA damaging agents.

Bone marrow granulocyte-macrophage-colony forming unit (CFU-GM) assays comparing the sensitivity of bone marrows across species have been useful in predicting the blood levels of agents that might be tolerated in patients compared with blood levels in preclinical efficacy and safety species (11). For many cytotoxic agents, the bone marrow of mice is less sensitive than is human bone marrow, thus allowing blood levels to be achieved in preclinical efficacy testing that can not be reached in patients. The toxicity of three nucleoside analogs toward murine and human bone marrow progenitor cells was examined (Table I) (11-15). The differential sensitivity between the cells from these two species to the nucleoside analogs may explain, in part, the difference in effects of these compounds in patients compared to preclinical studies. There is also a large differential in the sensitivity of human bone marrow CFU-GM to these three closely related drugs. Cladribine is 70 - to 80 -fold more potent than fludarabine in killing human bone marrow CFU-GM. Clofarabine is 16- to 22-fold more potent than fludarabine in killing human bone marrow CFU-GM. The small differences in chemical structures of these compounds result in biologically important difference in transport and intracellular metabolism to active cytotoxic species. Pessina (11) reported fludarabine $\mathrm{IC}_{50}$ and $\mathrm{IC}_{90}$ values in the mouse of $11.1 \mu \mathrm{g} / \mathrm{ml}$ and $17.2 \mu \mathrm{g} / \mathrm{ml}$ and $\mathrm{IC}_{50}$ and $\mathrm{IC}_{90}$ values in the human of $0.3 \mu \mathrm{g} / \mathrm{ml}$ and $0.58 \mu \mathrm{g} / \mathrm{ml}$, respectively. These values are in reasonable agreement with the current study with fludarabine $\mathrm{IC}_{50}$ and $\mathrm{IC}_{90}$ values in the mouse of $2.7 \mu \mathrm{g} / \mathrm{ml}$ and $>8.6 \mu \mathrm{g} / \mathrm{ml}$ and $\mathrm{IC}_{50}$ and $\mathrm{IC}_{90}$ values in the human of 0.063 and $0.2 .3 \mu \mathrm{g} / \mathrm{ml}$, respectively. Pessina (11) went further to suggest that through use of the ratio between mouse and human CFU-GM IC values as well as the maximum tolerated dose of the compound in mice, the maximum tolerated dose of the compound in patients could be predicted and a therapeutic blood level in patients estimated.

Clofarabine was a more active and effective anticancer drug than fludarabine in most of the human tumor xenograft models tested except in the $\mathrm{PC}-3$ prostate carcinoma where both drugs markedly slowed tumor growth (Figs. 4-6).
Clofarabine was a very effective anticancer agent in the RL lymphoma, RPMI-8226 multiple myeloma and the PC-3 protstate carcinoma when administered by intraperitoneal injection. Daily oral administration of clofarabine was also a highly effective therapy against the HT29 colon carcinoma xenograft.

Bone marrow colony formation assays continue to be useful in the translation of preclinical mouse safety and efficacy results to the clinic. The mouse tends to be more tolerant to xenobiotics than are humans; however, through the application of translational techniques, more accurate interpretation of preclinical tumor models may be achieved (44). The toxicity profile of clofarabine is different from fludarabine and cladribine. It has clinical activity when used as a single agent against adult leukemias at tolerable doses. Exploration of additional schedules, routes of administration and combinations (45-47) could exploit the full potential of clofarabine in the clinic.

\section{References}

1. Rustum YM (ed.): Fluoropyrimidines in Cancer Therapy. Humana Press, New York, 2003.

2. Karp JR, Peters GJ and Nagourney RA: Clinical activity of gemcitabine as a single agent and in combination. In: Deoxynucleoside Analogs in Cancer Therapy. Peters GJ (ed.) Humana Press, New York, pp253-288, 2006

3. Hande KR and Garrow GC: Purine antimetabolites. In: Cancer Chemotherapy and Biotherapy: Principles and Practice. Chabner BA and Longo DL (eds.) Lippincott-Raven, New York, pp235-252, 1996.

4. Bonate PL, Arthaud L, Cantrell WR Jr, Stephenson K, Secrist JA III and Weitman S: Discovery and development of clofarabine: a nucleoside analogue for treating cancer. Nat Rev Drug Discov 5: 855-863, 2006.

5. Pui CH, Jeha S and Kirkpatrick P: Clofarabine. Nat Rev Drug Discov 4: 369-370, 2005.

6. Faderl S, Gandhi V, Keating M, Jeha S, Plunkett W and Kantarjian $\mathrm{H}$ : The role of clofarabine in hematologic and solid malignancies - development of a next-generation nucleoside analog. Cancer 103: 1985-1995, 2005.

7. Xie C and Plunkett W: Metabolism and actions of 2-chloro-9(2-deoxy-2-fluoro- $B$-D-arabinofuranosyl)adenine in human lymphoblastoid cells. Cancer Res 55: 2847-2852, 1995.

8. Parker WB, Allan PW, Hassan AE, Secrist JA III, Sorscher EJ and Waud WR: Antitumor activity of 2-fluoro-2'-deoxyadenosine against tumors that express Escherichia coli purine nucleoside phosphorylase. Cancer Gene Ther 10: 23-29, 2003.

9. Xie KC and Plunkett W: Deoxynucleotide pool deletion and sustained inhibition of ribonucleotide reductase and DNA synthesis after treatment of human lymphoblastoid cells with 2chloro-(2-deoxy-2-fluoro- $\beta$-D-arabinofuranosyl)adenine. Cancer Res 565: 3030-3037, 1996.

10. Genini D, Adachi, S, Chao Q, et al: Deoxyadenosine analogs induce programmed cell death in chronic lymphocytic leukemia cells by damaging the DNA and by directly affecting the mitochondria. Blood 96: 3537-3543, 2000.

11. Pessina A: Application of the CFU-GM assay to predict acute drug-induced neutropenia: an international blind trial to validate a prediction model for the maximum tolerated dose (MTD) of myelosuppressive xenobiotics. Toxicol Sci 75: 355-367, 2003.

12. Kummar S, Gutierrez M, Doroshow JH and Murgo AJ: Drug development in oncology: classical cytotoxics and molecularly targeted agents. Br J Clin Pharmacol 62: 15-26, 2006.

13. Masubuchi N, May RD and Atsumi R: A predictive model of human myelotoxicity using five camptothecin derivatives and the in vitro colony-forming unit granulocyte/macrophage assay. Clin Cancer Res 10: 6722-6731, 2004.

14. Erickson-Miller CL, May RD, Tomaszewski J, Osborn B, Murphy MJ, Page JG and Parchment RE: Differential toxicity of camptothecin, topotecan and 9-aminocamptothecin to human, canine, and murine myeloid progenitors (CFU-GM) in vitro. Cancer Chemother Pharmacol 39: 467-472, 1997. 
15. Kurtzberg LS, Battle T, Rouleau C, et al: Bone marrow and tumor cell CFU and human tumor xenograft efficacy of noncamptothecin and camptothecin topoisomerase I inhibitors. Mol Cancer Ther 7: 3212-3222, 2008.

16. Beckwith M, Longo DL, O'Connell CD, Moratz CM and Urba WJ: Phorbol ester-induced cell cycle-specific growth inhibition of human B-lymphoma cell lines. J Natl Cancer Inst 82: 501-509, 1990

17. Matsuoka Y, Moore GE, Yagi Y and Pressman D: Production of free light chains of immunoglobulin by a haematopoietic cell line derived from a patient with multiple myeloma. Proc Soc Exp Biol Med 125: 1246-1250, 1967.

18. Kaighn ME, Narayan KS, Ohnuki Y, Lechner JF and Jones LW: Establishment and characterization of a human prostatic carcinoma cell line (PC-3). Invest Urol 17: 16-23, 1979.

19. Fogh J (ed.): In: Human Tumor Cells In Vitro 43. Plenum Press, New York, pp115-159, 1975

20. Belani R and Saven A: Cladribine in hairy cell leukemia. Hematol Oncol Clin North Am 20: 1109-1123, 2006.

21. Gidron A and Tallman MS: 2-CdA in the treatment of hairy cell leukemia: a review of long-term follow-up. Leuk Lymphoma 47: 2301-2307, 2006.

22. Robak T: The place of cladribine in the treatment of chronic lymphocytic leukemia: a 10-year experience in Poland. Ann Hematol 84: 63-70, 2005

23. Robak T, Wierzbowska A and Robak E: Recent clinical trials of cladribine in hematological malignancies and autoimmune disorders. Rev Rec Clin Trials 1: 15-34, 2006.

24. Carson DA, Wasson DB, Kaye J, Ullman B, Martin DW Jr Robins RK and Montgomery JA: Deoxycytidine kinase-mediated toxicity of deoxyadenosine analogs toward malignat human lymphoblasts in vitro and toward murine L1210 leukemia in vivo. Proc Natl Acad Sci USA 77: 6865-6969, 1980.

25. Carson DA, Wasson DB and Beutler E: Antileukemic and immunosuppressive activity of 2-chloro-2'-deoxyadenosine. Proc Natl Acad Sci USA 81: 2232-2236, 1984.

26. Avramis VI, Wiersman S, Krailo MD, et al: Pharmacokinetic and pharmacodynamic studies of fludarabine and cytosine arabinoside administered as loading boluses followed by continuous infusions after a Phase I/II study in pediatric patients with relapsed leukemias. Clin Cancer Res 4: 45-52, 1998.

27. Robak T and Robak P: Current treatment options in prolymphocytic leukemia. Med Sci Monit 13: RA69-RA80, 2007

28. Slugoski MD, Smith KM, Mulintas R, et al: A conformationally mobile cysteine residue (C561) modulates $\mathrm{Na}^{+}$- and $\mathrm{H}^{+}$-activation of human concentrative nucleoside transporter 3. J Biol Chem 283: 24922-24934, 2008.

29. Zhang J, Visser F, King KM, Baldwin SA, Young JD and Cass CE: The role of nucleoside transporter in cancer chemotherapy with nucleoside drugs. Cancer Metastasis Rev 26: 85$110,2007$.

30. Tsang RY, Santos C, Ghosh S, et al: Immunohistochemistry for human concentrative nucleoside transporter 3 protein predicts fludarabine sensitivity in chronic lymphocytic leukemia. Mod Pathol 21: 1387-1393, 2008.

31. Parker WB, Shaddix SC, Chang $\mathrm{CH}$, et al: Effects of 2-chloro9-(2-deoxy-2-fluoro-ß-D-arabinofuranosyl)adenine on K562 cellular metabolism and the inhibition of human ribonucleotide reductase and DNA polymerases by its 5 '-triphosphate. Cancer Res 51: 2386-2394, 1991.

32. Carson DA, Wasson DB, Esparza LM, Carrera CJ, Kipps TJ and Cottam HB: Oral antilymphocyte activity and induction of apoptosis by 2-chloro-2'-arabino-fluoro-2'-deoxyadenosine. Proc Natl Acad Sci USA 89: 2970-2974, 1992.
33. King KM, Damaraju VL, Vickers MF, et al: A comparison of the transportability, and its role in cytotoxicty, of clofarabine, cladribine, and fludarabine by recombinant human nucleoside transporters produced in three model expression systems. Mol Pharmacol 69: 346-353, 2006.

34. Gradhand U and Kim RB: Pharmacogenomics of MRP transporters (ABCC1-5) and BCRP (ABCG2). Drug Metab Rev 40: 317-354, 2008.

35. Ravna AW, Sylte I and Sager G: Molecular model of the outward facing state of the human P-glycoprotein (ABCB1) and comparison to a model of the human MRP5 (ABCC5). Theor Biol Med Mod 4: 33-46, 2007.

36. Sampath J, Adachi M, Hatse S, et al: Role of MRP4 and MRP5 in biology and chemotherapy. AAPS Pharm Sci 4: 1-9, 2002.

37. Wielinga PR, Reid G, Challa EE, et al: Thiopurine metabolism and identification of the thiopurine metabolites transported by MRP4 and MRP5 overexpressed in human embryonic kidney cells. Mol Pharmacol 62: 1321-1331, 2002.

38. Lotfi K, Mansson E, Spasokoukotskaja T, et al: Biochemical pharmacology and resistance to 2-chloro-2'-arabino-fluoro-2'deoxyadenosine, a novel analog of cladribine in human leukemic cells. Clin Cancer Res 5: 2438-2444, 1999.

39. Gandhi V. Kemena A, Keating MJ and Plunkett W: Cellular pharmacology of fludarabine triphosphate in chronic lymphocytic leukemia cells during fludarabine therapy. Leuk Lymphoma 10: 49-56, 1993.

40. Gandhi V and Plunkett W: Clofarabine: mechanisms of action, pharmacology and clinical investigations. In: Deoxynucleoside Analogs in Cancer Therapy. Peters GJ (ed.) Humana Press, New York, pp153-171, 2006.

41. Takahashi T, Kanazawa J, Akinaga S, Tamaoki T and Okabe M: Antitumor activity of 2-chloro-9-(2-deoxy-2-fluoro- $B$-D-arabinofuranosyl)adenine, a novel deoxyadenosine analog, against human colon tumor xenografts by oral administration. Cancer Chemother Pharmacol 43: 233-240, 1999.

42. Kantarjian H, Gandhi V, Kozuch P, et al: Phase I clinical and pharmacology study of clofarabine in patients with solid and hematologic cancers. J Clin Oncol 21: 1167-1173, 2003.

43. Chiao N, Bumgardner A and Duvic M: Clofarabine-induced acral erythema during the treatment of patients with myelodysplasia and acute leukemia: report of two cases. Leuk Lymphoma 44: 1405-1407, 2003.

44. Peterson JK and Houghton PJ: Integrating pharmacology and in vivo cancer models in preclinical and clinical drug development. Eur J Cancer 40: 837-844, 2004.

45. Karp JE, Ricklis RM, Balakrishnan K, et al: A phase I clinicallaboratory study of clofarabine followed by cyclophosphamide for adults with refractory acute leukemias. Blood 110: 1762-1769, 2007.

46. Faderl S, Gandhi V, O'Brien S, et al: Results of a phase 1-2 study of clofarabine in combination with cytarabine (ara-C) in relapsed and refractory acute leukemia. Blood 105: 940-947, 2005.

47. Faderl S, Ravandi F, Huang X, et al: A randomized study of clofarabine versus clofarabine plus low dose cytarabine as frontline therapy for patients age $\geq 60$ years with acute myeloid leukemia and high risk myelodysplastic syndrome. Blood 112: $1638-1645,2008$ 